\title{
Differentiation of Seasonal Generations of Field Voles on Bone Adhesion Lines
}

\section{Galina A. KLEVEZAL, Michalina PUCEK \& Evgenija P. MALAFEEVA.}

Klevezal G. A., Pucek M. \& Malafeeva E. P., 1985: Differentiation of seasonal generations of field voles on bone adhesion lines. Acta theriol., 30, 23: $349-358$ [With 2 Tables \& Plate VI]

Examination was made of the histological structure of the mandibular bones of 191 field voles, Microtus agrestis (Linnaeus, 1761), belonging to the spring $(n=104)$ and autumn generation $(n=87)$. Animals of known age were obtained from laboratory breeding. A description is given of variations with the voles' age in the formation of adhesion lines. The same material was arranged in calendar order. The frequency of individuals with different bone structure (of different age) was examined in different months, which showed that during the summer-autumn period it was possible to distinguish between individuals of the spring and autumn generations in samples from natural populations, although such differentiation was possible only in part of the material at other times of the year.

[Kolcov's Inst. of Developmental Biology, USSR Acad. Sci., $26 \mathrm{Va}-$ vilov Str., 117334 Moscow, USSR (GAK, EPM), and Mammals Res. Inst., Polish Acad. Sci., 17-230 Białowieża, Poland (MP)]

\section{INTRODUCTION}

As in the case of other mammals, adhesion lines, forming in winter and visible in animals which had overwintered, appear in the bones of field voles (Klevezal \& Kleinenberg, 1967). The number of lines does not necessarily correspond to the number of winters survived by the animals. In old adults of $M$. agrestis there may be from 2 to 6 such lines (Klevezal \& Fedyk, 1978).

M. agrestis attains sexual maturity most often at the age of $50-60$ days. The reproduction season may last, depending on the climatic zone, from February to November. Winter reproduction has also been observed (France, Germany). Animals born in spring reproduce in the same calendar year, and the largest number of gestating females is encountered in June and July (Krapp \& Niethammer, 1982).

Under natural conditions maximum survival of $M$. agrestis is estimated to be from 420-450 days (Myllymäki, 1977), whereas the physiological age limit is from 15-18 months (Reichstein, 1958/59; Myllymäki, 1977). These animals do not therefore survive through two winters and two or three seasonal generations may occur in the population depending on the time of year. Under laboratory breeding conditions: 
the animals' survival time is understandably far longer and may be as much as 39 months (Gębczyńska, 1964).

It has been shown previously that with voles it is possible to distinguish overwintered animals from the current year's individuals by the number of adhesion lines in the mandible, and first attempts have been made to differentiate between members of the spring and autumn generation among old adult animals (Klevezal \& Fedyk, 1978; Ivashkina \& Klevezal, 1980). The purpose of the present study was to trace the dynamics of appearance of adhesion lines in field voles of the spring and autumn generations, and also to determine to what degree it is possible to differentiate individual of the two generations in samples taken from a population at different seasons of the year.

\section{MATERIAL AND METHODS}

The mandibles of 191 field voles, Microtus agrestis (Linnaeus, 1761), obtained from laboratory breeding in the Mammals Research Institute, Polish Academy of Sciences, at Białowieża, were taken for analysis. 104 of these animals were born during the period, between 28th March and 30th April 1980 and 1982 (spring generation), and 87 animals in autumn between 4th August and 19th September 1980 and 1981. Detailed data on breeding of these animals and a description of materiai are to be found in the previous study made on the same material (Klevezal et al., 1984).

The field voles were killed at the age of 1.5 to 13 months. Microscopic sections from the mandible were stained with hematoxylin using the methods accepted by Klevezal \& Fedyk (1978).

Adhesion lines were counted on the mandible sections in the region of $\mathrm{M}_{3}$. The following were distinguished: (1) basic lines - which run distinctly along the base of the mandible and usually enter into the buccal part, and (2) supplementary lines - usually only weakly contrasting, visible in some parts of the section and disappearing in others. Three observers with different degrees of experience made independent initial estimates of the number of basic and supplementary adhesion lines and their character (single, grouped, etc.). It was found that complete agreement in description of the structure of adhesion lines was obtained only in $14 \%$ of the cases. With two observers this agreement was est:mated as $54 \%$. In $36 \%$ of the cases the discrepancy related to estimate of supplementary lines and in $30 \%$ differentiation between basic and supplementary lines. In order to obtain the most objective estimate including all variants of adhesion lines 5 categories of individuals were finally distinguished: I - without adhesion lines (Photo. 1, see Plate VI); II - with one or more supplementary lines (Photo. 2); III - with one basic line, with or without supplementary lines (Photo. 3); IV - with two basic lines, with or without supplementary lines (Photo. 4); V - with three or more basic lines or groups of lines, also with or without supplementary lines (Photo. 5), It was then found that the results obtained by the three observers agreed in $47 \%$ of the cases, and in $92 \%$ with two observers. On this account division into 5 categories and estimates by one, 
most highly experienced observer, were accepted in further work on the preparations.

Fisher's test was used for statistical elaboration, using Plohinski's textbook (1961) and Rolf \& Sokal's tables (1981).

\section{RESULTS}

The frequency of occurrence of the variants of adhesion lines distinguished in the mandible of $M$. agrestis was compared for two different generations and different ages. It can be seen from Table 1 that the group of youngest animals, up to 2 months old, does not, in the majority of cases, exhibit any adhesion lines. Supplementary lines are observed in animals from 2-4 months old. As from the 6th month of life basic adhesion lines appear, the number of which increases with

Table 1

Frequency of occurrence of five (I-V, see Plate VI)) categories of adhesion lines in the mandible of $M$. agrestis belonging to two seasonal generations. Two variants (A, B) of grouping of the same material.

\begin{tabular}{|c|c|c|c|c|c|c|c|c|c|c|c|c|}
\hline \multirow{2}{*}{ Age, days } & \multicolumn{6}{|c|}{ Spring generation } & \multicolumn{6}{|c|}{ Autumn generation } \\
\hline & $\mathrm{n}$ & I & II & III & IV & v & $\mathbf{n}$ & I & II & III & IV & V \\
\hline \multicolumn{13}{|l|}{ A } \\
\hline $1-56$ & 11 & 10 & 1 & & & & 8 & 6 & 2 & & & \\
\hline $57-112$ & 25 & 6 & 18 & 1. & & & 15 & 4 & 10 & 1 & & \\
\hline $113-168$ & 16. & & 14 & 2 & & & 21 & & 10 & 10 & 1 & \\
\hline $168-224$ & 16 & & 3 & 13 & & & 16 & & 3 & 8 & 3 & 2 \\
\hline $225-280$ & 17 & & 2 & 15 & & & 14 & & & 2 & 5 & 7 \\
\hline $281-336$ & 10 & & 1 & 4 & 3. & 2. & 8 & & & & 2 & 6 \\
\hline $337-392$ & 9 & & & & 4 & 5 & 5 & & & & 3 & \\
\hline \multicolumn{13}{|l|}{$\mathrm{B}$} \\
\hline $29-84$ & 22 & 16 & 6 & & & & 16 & 10 & 6 & & & \\
\hline $85-140$ & 19 & & 18 & 1. & & & 17 & & 12 & 4 & 1 & \\
\hline $141-196$ & 23 & & 10 & 13 & & & 14 & & 4. & 10 & & \\
\hline $197-252$ & 12 & & 2 & 10. & & & 20 & & 3 & 5 & 6 & \\
\hline $253-308$ & 15 & & & 12 & 1. & 2 & 10 & & & 2 & 4 & \\
\hline $309-364$ & 13 & & & 1 & 6 & 6 & 10 & & & & 3 & 7 \\
\hline
\end{tabular}

age. It was not, however, possible to differentiate between spring and autumn individuals in any age class by the number of adhesion lines, although there were more of these in the autumn animals.

In samples taken from natural populations there may also simultaneously be individuals of the autumn and spring generations, differing in age, at least by two months.

In order to be able to compare the character of adhesion lines in each age class for the two generations, the initial material was arranged in eight-week intervals in two ways: (A) $1-56$ days, $57-112$, etc., and (B) $29-84$ days, $85-140$, etc. (Table 1 ). 
Assuming that intensive reproduction of field voles begins under natural conditions towards the end of March and beginning of April, and ends towards the end of September and beginning of October, the material obtained from laboratory breeding is shown in Table 2. Animals of either known or assumed (marked with an asterisk) age and season of birth have been compared and analyzed as though they had been caught in natural populations in successive months of the year.

1 gldist groni ngoa gd aso fl Table 2

Frequency of encounter of the different categories of adhesion lines in the mandible of $M$. agrestis belonging to different seasonal generations in successive months of the year, on the basis of material in Table 1.

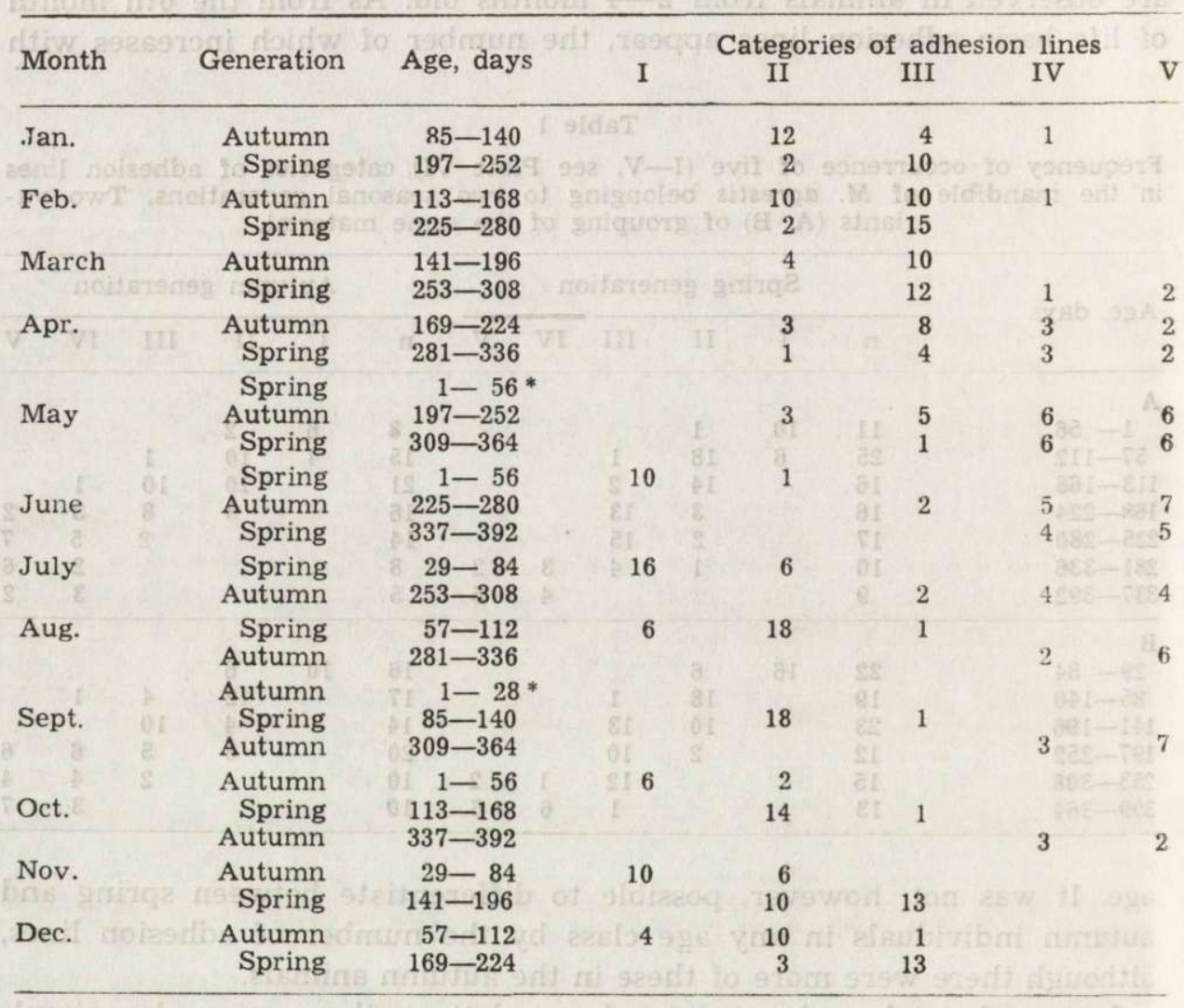

* No adhesion lines in the mandibles of animals of this age.

It can be seen from Table 2 that in January and February there may be individuals of the autumn and spring generations which have supplementary lines only, and also one basic lines, in their mandible, (there are far fewer spring individuals with supplementary lines II). It is possible by using Fisher's test to differentiate, with a high degree of 
probability, between animals of the spring and autumn generations from the frequency of occurrence of category II individuals in relation to the total number of individuals (categories II+III), omitting in this case single animals belonging to category IV. For instance, for January samples $F_{\mathrm{II}}=10.6, p<0.01$; in February $F_{\mathrm{II}}=6.85, p<0.05$. Accepting $95 \%$ confidence interval the proportion of animals with supplementary lines in the mandible in the autumn generation was $0.75 \pm 0.23$ in January, i.e. from 0.53 to 0.98 , and in February $0.50 \pm 0.23$, i.e. from 0.27 to 0.73 . It is therefore possible to determine, in samples caught from natural populations during this time, whether they contain autumn generation animals or individuals from other seasonal generations. If the ratio of animals with supplementary lines (II) to the sum total of animals having supplementary lines and one basic line (II + III) is lower than 0.52 in January and than 0.27 in February, then not only autumn generations individuals are present in the sample.

In March - an attempt may be made to differentiate between individuals of the autumn and spring generations by means of the proportion of animals having only supplementary lines (category II). $F_{11}=9.37, p<0.05$. The confidence interval for animals in this category in the autumn generation is $0.29 \pm 0.28$. Practically speaking this does not permit of determining whether the March sample consists only of autumn generation animals, but use may be made here of the presence or absence of animals with two or more basic lines in the mandible (categories IV and V). The number of such autumn generation individuals was 0 . With small samples the $95 \%$ confidence interval was from 0 to 0.18 . A value lower than 0.18 , obtained for individuals having two or more adhesion lines in the sample obtained in March means that not only autumn generation animals will be present in it.

In April, according to our data, it proved impossible to distinguish between autumn and spring generation individuals.

In May - old adults of the autumn and spring generations can be distinguished in the category of animals with supplementary lines and one basic line (II and III), where $F_{I I+I I I}=4.99, p<0.05$. The confidence interval for this group of autumn generation animals was $0.40 \pm 0.23$. This means that with a value lower than 0.17 , obtained for this category of animals, there will be old adults in the spring sample not only from the autumn generation. In addition among animals caught in May there may also be the current year's spring animals which can be easily distinguished since they have no adhesion lines in the mandibular bone.

Among animals caught in June it is theoretically possible to encounter three groups: the current year's spring animals and old adults 
born the previous spring and autumn. The current year's spring animals have no basic adhesion lines and this differs them from old adults. $F_{1+\text { II }}=73.4, p<0.001$. In respect of old adults, although the spring individuals have more basic lines, the differences in our fairly scanty material were not significant: $F_{\mathrm{III}}=3.22, p>0.05$.

In July, August and September old adults significantly differed from the current year's animals, since the former had two or more basic lines in the mandibular bone. For July $F_{\mathrm{IV}+\mathrm{V}}=38.09, p<0.001$ : in August $F_{\mathrm{IV}+\mathrm{V}}=59.8, p<0.001$; in September $F_{\mathrm{IV}+\mathrm{V}}=64.65, p<0.001$. It may be anticipated that in September the sample will contain autumn generation animals born the current year, which will have no adhesion lines at all (I) in the mandibular bone and which can be differentiated without difficulty. Individuals born in summer, on the other hand, should occupy, on the basis of their adhesion lines, a place intermediate between spring and autumn generation animals (categories II and III).

In October - only old adults of the previous autumn, if they have survived so long, can be distinguished from the current year's animals by the presence of two or more adhesion lines in the mandible, $F_{\mathrm{IV}+\mathrm{V}}=$ $=40.53, p<0.001$. The spring and autumn generations of the current year cannot be distinguished in October, or in November and December. Both generations have supplementary lines in the mandible (II). Only a certain number of the individuals of autumn generation without adhesion lines can be differentiated. $F$ value calculated for the above months are respectively: $F_{1}=22.0, p<0.001 ; F_{1}=31.00, p<0.001 ; F=8.8$, $p<0.05$.

In November and December the spring generation may be distinguished from the autumn generation by the presence of individuals with one basic adhesion line in the mandible, $F_{\text {III }}=22.0$ and 27.0, $p<0.001$. Thus in samples from populations in the two final months of the year, animals without adhesion lines will belong to the autumn generation and those with one basic line to the spring generation. Those animals, on the other hand, with supplementary lines in the mandibular bone, may belong to either the spring or the autumn generation. The majority of summer generation animals also come within this category, and in respect of the mandibular bone structure should occupy an intermediate place between spring and autumn animals.

\section{DISCUSSION}

The results presented are based on age changes in the bone tissue structure in field voles living under laboratory conditions. The question therefore arises as to what degree the results obtained can relate to animals living under natural conditions. In our experiment the natural 
light ryhtm was adhered to, since this is known to affect growth and development of rodents. The voles had partly differing diet in different seasons. They were supplied with beets and oats throughout the whole experiment, hay in winter and during the growing season green grasses with an admixture of clover and Taraxacum officinale. Similar varied diet is consumed by voles under natural conditions (Hansson, 1971). The basic difference, however, consisted in the experimental voles not being allowed to reproduce, although other experiments have shown that in the case of selected rodents and predators, gestation and lactation do not inhibit skeletal growth and do not affect the formation of adhesion lines in bones (Klevezal \& Mina, 1973; Klevezal \& Mina, in press).

The results presented above, and also the results of earlier studies, show that laboratory breeding without standardized illumination programme, food and humidity, permits of maintaining differentiation in rate of growth and development of the rodents depending on the season of their birth (Fedyk, 1974a, 1974b; Klevezal et al., 1984). The differences we found in structure and rate of formation of adhesion lines in the mandibular bone may therefore give a good picture of the differentiation existing in nature. It may thus be assumed that under natural conditions these differences will be manifested at least to the degree presented in this paper.

Definition of the age of adult rodents of the Arvicolidae family, which have rootless teeth, presents ecologists with serious difficulty. It is not possible to distinguish between young and adult animals as from the third month of life on the basis of body weight. There is an additional difficulty in distinguishing between individuals from different seasonal generations. It is of course possible to mark rodents appearing in the population and to continue to trace the various cohorts or generations (Gliwicz et al., 1968), but there is no method for such an analysis ex post. It would seem that the results presented here, although far from ideal, permit of differentiating between individuals of different seasonal generations during the summer-autumn period (July-September), although at other times of the year only part of the material can be so differentiated.

Acknowledgements: Thanks are due to Dr. M. V. Mina and Professor Z. Pucek for critical reading of the first draft of this paper, and also to N. V. Peremyslova for technical assistance. This paper is the result of bilateral co-operation between the Mammals Res. Inst. of the Polish Academy of Sciences and N. K. Kolcov's Institute of Developmental Biology of the USSR Academy of Sciences.

\section{REFERENCES}

1. Fedyk A., 1974a: Gross body composition in the postnatal development of the bank vole. I. Growth under laboratory conditions. Acta theriol., 19: 381-401. 
2. Fedyk A., 1974b: Gross body composition in the postnatal development of the bank vole. II. Differentiation of seasonal generations. Acta theriol., 19: $403-427$.

3. Gębczyńska Z., 1964: Morphological changes occurring in laboratory Microtus agrestis with age. Acta theriol., 9: 67-79.

4. Gliwicz J., Andrzejewski R., Bujalska G. \& Petrusewicz K., 1968: Productivity investigation of an island population of Clethrionomys glareolus (Schreber, 1780). Dynamics of cohorts. Acta theriol., 13: 401-413.

5. Hansson L., 1971: Small rodent food, feeding and population dynamics. A comparison between granivorous and herbivorous species in Scandinavia. Oikos, 22: $183-198$.

6. Ivashkina I. N. \& Klevezal G. A., 1980: Age determination by the layered bone structure in Microtus oeconomus Pall. Zool. Ž., 59: 1085-1091 [In Russian with English summ.].

7. Klevezal G. A. \& Fedyk A., 1978: Adhesion lines pattern as in indicator of age in voles. Acta theriol., 23: 413-422.

8. Klevezal G. A., \& Kleinenberg S. E., 1967: Age determination of mammals by layered structure in teeth and bone. Izd. Nauka: 1-144. Moskva. [In Russian].

9. Klevezal G. A. \& Mina M. W., 1973: Factors determining the pattern of annual layers in the dental tissue and bones of mammals. Ž. obšč. Biol., 34: 594-605 [In Russian with English summ.].

10. Klevezal G. A., Pucek M. \& Malafeeva E. P., 1984: Body and skeleton growth in laboratory field voles of different seasonal generations. Acta theriol., 29: $3-16$.

11. Krapp F. \& Niethammer J., 1982: Microtus agrestis (Linnaeus, 1761) - Erdmaus. [In: "Handbuch der Säugetiere Europas", Eds J. Niethammer \& E. Krapp]. Akad. Verlagsgesel. Bd 2/I: 349-373. Wiesbaden.

12. Myllymäki A., 1977: Demographic mechanisms in the fluctuating populations of the field vole Microtus agrestis. Oikos, 293: 468-493.

13. Plohinskij N. A., 1961: Biometrija. Izd. Sibirskovo otd. AN SSSR: 1-364. Novosybirsk.

14. Reichstein H., 1958/59: Populationsstudien an Erdmäusen, Microtus agrestis L. (Markienrungsversuche). Zool. Jb. (Syst.), 86: 367-382.

15. Rohlf J. \& Sokal R. R., 1981: Statistical tables. Sec. ed., Freeman: 1-219. San Francisco.

Accepted, 24 May, 1985. 
Galina A. KLEVEZAL, Michalina PUCEK \& Evgenija P. MALAFEeva

\section{ROZROŻNIENIE SEZONOWYCH GENERACJI U NORNIKA BUREGO NA PODSTAWIE LINII SKLEJANIA KOSCI}

\section{Streszczenie}

Zbadano histologiczną strukturę kości żuchwy 191 norników Microtus agrestis (Linnaeus, 1761), osobników generacji wiosennej $(n=104)$ i jesiennej $(n=87)$, zwierząt o znanym wieku, z hodowli laboratoryjnej. Na skrawkach barwionych hematoksyliną liczono linie sklejania. Wyróżniono 5 kategorii osobników, obejmujących wszystkie występujące warianty linii sklejania kości (Plate VI).

Materiał wyjściowy zestawiono tak, by można było prześledzić zmiany powstawania linii w każdym przedziale wiekowym obydwu generacji (Tabela 1). Ten sam materiał uszeregowano w układzie kalendarzowym i w poszczególnych miesiącach analizowano frekwencję osobników o różnym wieku i różnej strukturze kości (Tabela 2). Na tej podstawie wykazano, że w okresie letnio-jesiennym można by odróżnić osobniki generacji wiosennej i jesiennej w próbach branych z populacji naturalnych. W pozostałych porach roku rozróżnienia takie sa możliwe tylko w odniesieniu do części materiału. 


\section{EXPLANATION OF PLATE VI}

Lower margin of the mandibular shaft of $M$. agrestis in the region of $\mathbf{M}_{3}$ with visible adhesion lines. Cross-sections stained with hematoxylin.

Photo 1. Bone without adhesion lines - category I.

Photo 2. Only supplementary lines - category II.

Photo 3 . One basic line (indicated by arrow) - category III.

Photo 4. Two basic lines (indicated by arrow) - category IV.

Photo. 5. Groups of lines - category V. 


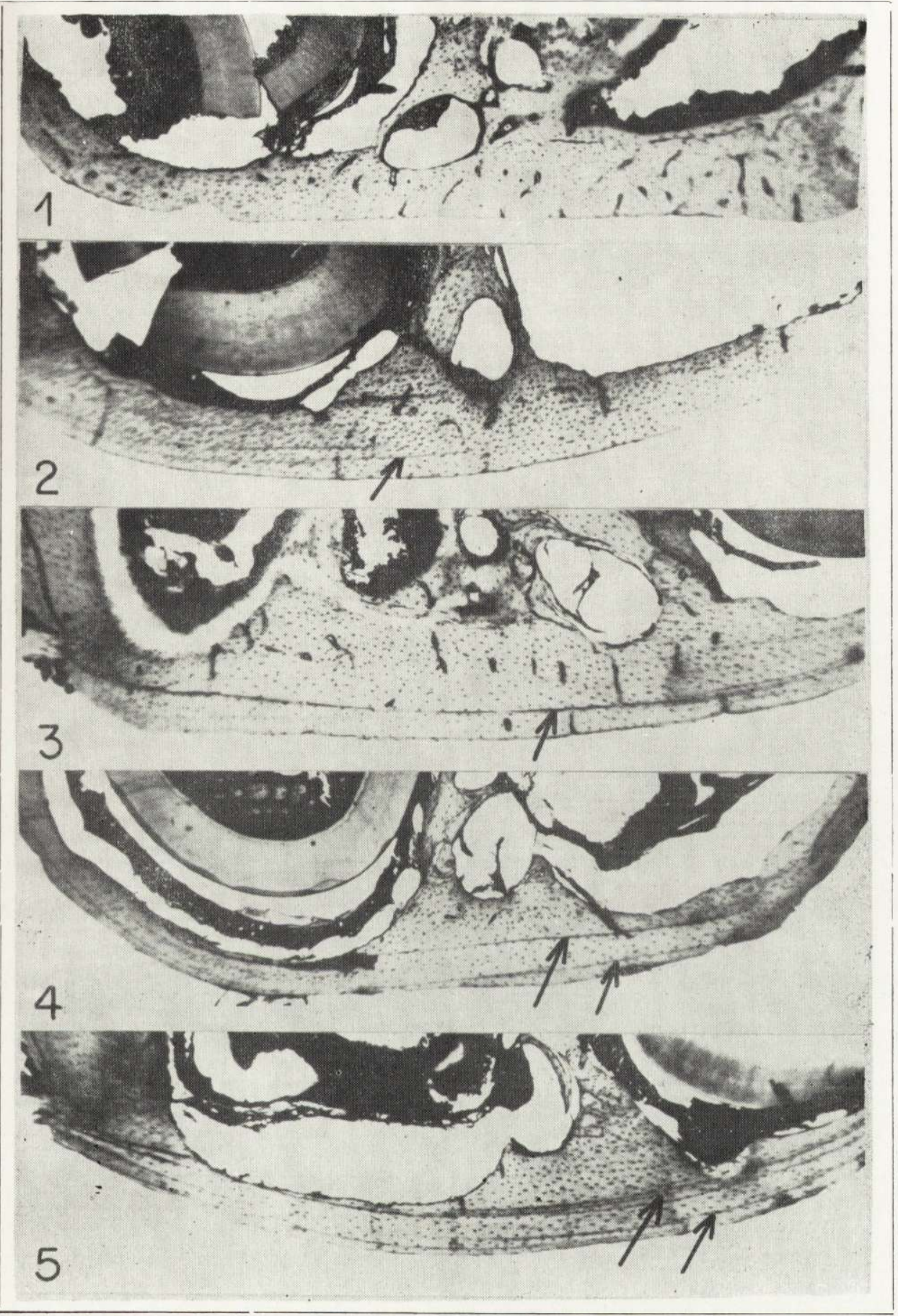

G. A. Klevezal et al.

auctores phot. 